\title{
Karolina Nartowska
}

Universität Wien

karolina.nartowska@interia.eu

\section{USTAWA O ZAWODZIE TŁUMACZA PRZYSIĘGŁEGO A TŁUMACZENIE SĄDOWE W POLSCE}

DOI: http://dx.doi.org/10.12775/RP.2018.010

\begin{abstract}
Zarys treści: W zjednoczonej Europie tłumacze sądowi odgrywają kluczową rolę w dwujęzycznych postępowaniach, co podkreślają przepisy dyrektywy 2010/64/UE o prawie do tłumaczenia ustnego i pisemnego w postępowaniu karnym. W Polsce działalność tłumaczy sądowych reguluje Ustawa o zawodzie tłumacza przysięgłego. W niniejszym artykule krytycznej refleksji - w świetle przepisów wspólnotowych oraz Ustawy - poddana zostanie obecna sytuacja tłumaczenia sądowego w Polsce, przede wszystkim zapotrzebowanie sądów, kształcenie tłumaczy sądowych, problemy w praktyce oraz jakość tłumaczenia w sądzie. Analiza pozwala na wysunięcie postulatów umożliwiających optymalizację przepisów Ustawy z jednej oraz aktualnej sytuacji z drugiej strony.
\end{abstract}

Słowa kluczowe: tłumaczenie sądowe, tłumacz przysięgły, jakość tłumaczenia

\section{Wprowadzenie}

10-lecie wejścia w życie Ustawy o zawodzie tłumacza przysięgłego to dobry moment na podsumowania i refleksję. Polska Ustawa stanowi obecnie najlepsze uregulowanie działalności tłumacza przysięgłego/sądowego w Europie (por. Hertog \& v. Gucht 2008: 173). Na wyróżnienie zasługują przepisy regulujące prawa i obowiązki polskich tłumaczy przysięgłych, zasady etyki, odpowiedzialność zawodową oraz kary dyscyplinarne. Podkreślić należy także obszerne unormowanie obligatoryjnego egzaminu państwowego dla kandydatów na tłumaczy przysięłych, a także prowadzenia ministerialnej listy tłumaczy przysięgłych (również 1. miejsce wśród krajów europejskich). 
Mimo tej laurki, na którą Ustawa niewątpliwie zasługuje, warto krytycznie spojrzeć na obecny stan tłumaczenia sądowego w Polsce - w świetle przepisów Ustawy o zawodzie tłumacza przysięgłego, a także prawa wspólnotowego, które ma pierwszeństwo przed prawem krajowym. Dlatego w niniejszym artykule, w oparciu o dane empiryczne, analizie poddane zostaną takie aspekty jak: rynek tłumaczenia sądowego, kształcenie tłumaczy sądowych, problemy w praktyce oraz jakość tłumaczenia w sądzie. Analiza umożliwi dostrzeżenie słabych punktów obecnej sytuacji oraz rozwiązań prawnych, co pozwoli na sformułowanie odpowiednich propozycji zmian.

\section{Przepisy prawa dotyczące tłumaczy sądowych}

\subsection{Przepisy wspólnotowe: prawo do tłumaczenia w postępowaniu karnym}

Dyrektywa Parlamentu Europejskiego i Rady 2010/64/UE w sprawie prawa do tłumaczenia ustnego i tłumaczenia pisemnego w postępowaniu karnym, której przepisy państwa członkowskie musiały implementować do prawa krajowego do 27 października 2013 r. (art. 9 ust. 1), gwarantuje, że każda podejrzana lub oskarżona osoba, która nie mówi bądź nie rozumie języka postępowania, otrzyma „darmową i odpowiednią pomoc językową" (pkt 17) ${ }^{1}$. Przyznając prawo do tłumaczenia, dyrektywa dąży do zachowania prawa osoby obcojęzycznej do rzetelnego procesu sądowego (pkt 14)². Rzetelny proces zapewniony jest wówczas, gdy osoba obcojęzyczna może w pełni wykonywać swoje prawo do obrony.

Dlatego dyrektywa stanowi, że osoba obcojęzyczna musi otrzymać tłumaczenie pisemne wszystkich dokumentów istotnych w postępowaniu (art. 3 ust. 1). W drodze wyjątku dopuszczalne jest zastąpienie tłumaczenia pisemnego „tłumaczeniem ustnym lub streszczeniem ustnym” (art. 3 ust. 7), pod warunkiem że pozostaje ono bez uszczerbku dla rzetelności postępowania. Ponadto dyrektywa gwarantuje każdej podejrzanej lub oskarżonej obcojęzycznej osobie tłumaczenie ustne podczas całego postępowania karnego (art. 2 ust. 1 i 2), a zatem przed organami śledczymi i sądowymi, podczas przesłu-

${ }^{1}$ Pomoc ta może nastąpić zarówno w języku ojczystym osoby podejrzanej lub oskarżonej, jak również w innym języku, którym dana osoba mówi lub który rozumie (pkt 22).

${ }^{2}$ Prawo do rzetelnego procesu, w tym również do bezpłatnego wsparcia językowego przez tłumacza ustnego w postępowaniu, ustanowione jest także przez prawo międzynarodowe, a w szczególności art. 5 i 6 Europejskiej Konwencji Praw Człowieka. 
chania przez policję oraz wszelkich rozpraw i posiedzeń sądowych, a także w czasie kontaktu podejrzanego lub oskarżonego z obrońcą.

Przepisy dyrektywy stanowią dalej, że jakość tłumaczenia pisemnego i ustnego w postępowaniu karnym musi być wystarczająca, by zagwarantować rzetelność postępowania. Jakość wystarczająca oznacza konieczność zapewnienia, że osoba obcojęzyczna wie, co jest jej zarzucane, zna dowody przeciwko niej i jest w stanie wykonywać swoje prawo do obrony (art. 3 ust. 9 i art. 2 ust. 8). Natomiast jeżeli osoba obcojęzyczna uzna, że jakość dostarczonego tłumaczenia pisemnego lub ustnego jest niewystarczająca dla zapewnienia rzetelnego procesu, ma ona prawo zakwestionować jakość tłumaczenia w formie złożenia skargi (art. 3 ust. 5 i art. 2 ust. 5). W związku z tym dyrektywa reguluje, że tłumaczenia pisemne i ustne muszą być wykonywane przez odpowiednio wykwalifikowanych tłumaczy specjalistycznych (pisemnych i ustnych), którzy posiadają kompetencję w zakresie terminologii prawniczej (pkt 31). Za podjęcie odpowiednich działań, zapewniających wymaganą jakość, a więc za kształcenie i dostarczenie wykwalifikowanych tłumaczy pisemnych i ustnych, odpowiedzialność ponoszą państwa członkowskie Unii Europejskiej (art. 5 ust. 1 i 2).

Kwalifikacje tłumaczy sądowych oraz jakość tłumaczenia pisemnego i ustnego znajdują po raz pierwszy uregulowanie w prawie wspólnotowym, co podkreśla ich wielkie znaczenie: nie są one już jedynie przedmiotem zainteresowań translatologii, a stają się obligatoryjnym, fundamentalnym wymogiem dla działalności tłumaczy prawniczych. Przepisy dyrektywy stanowią przy tym zaledwie minimalne standardy w postępowaniu karnym, a zatem wsparcie przyznane osobie obcojęzycznej może mieć szerszy - ale nie węższy zakres niż jest to przewidziane jej postanowieniami.

\subsection{Przepisy krajowe: Ustawa o zawodzie tłumacza przysiegtego}

Polska Ustawa o zawodzie tłumacza przysięgłego (Dz. U. z dnia 27.12.2004 r.) reguluje w sposób eksplicytny prawa i zadania tłumacza przysięgłego:

Art. 13. Tłumacz przysięgły jest uprawniony do:

1) sporządzania i poświadczania tłumaczeń $z$ języka obcego na język polski, z języka polskiego na język obcy;

[...]

3) dokonywania tłumaczenia ustnego.

$\mathrm{Z}$ przepisu tego wynika po pierwsze, że zawód tłumacza przysięgłego obejmuje zarówno działalność tłumacza pisemnego, jak i ustnego, a więc 
tłumacz przysięgły musi posiadać niezbędne kompetencje do wykonywania tłumaczeń pisemnych oraz tłumaczeń ustnych. Po drugie, tłumacz przysięgły w Polsce pełni funkcję tłumacza sądowego. Co więcej, tłumaczenie ustne w sądzie bądź dla organów państwowych stanowi jedno z podstawowych obowiązków ustawowych polskiego tłumacza przysięgłego:

Art. 15. Tłumacz przysięgły nie może odmówić wykonania tłumaczenia w postępowaniu prowadzonym na podstawie ustawy, na żądanie sądu, prokuratora, Policji oraz organów administracji publicznej, chyba że zachodzą szczególnie ważne przyczyny uzasadniające odmowę.

Ustawa nie określa przy tym, o jakie „szczególnie ważne przyczyny” odmowy chodzi. Stąd uzasadnione jest założenie, ze względu na ten rygorystyczny przepis ${ }^{3}$, że tłumacze przysięgli niezwykle rzadko (np. w przypadku ciężkiej choroby) będą mogli skorzystać z prawa do odmowy wykonania zlecenia na żądanie organów (Dostatni 2005: 97).

Pozostałe przepisy Ustawy określające dalsze obowiązki tłumaczy przysięgłych są ściśle związane z jakością tłumaczeń wykonywanych przez tłumaczy przysięgłych:

Art. 14. Tłumacz przysięgły jest obowiązany do:

1) wykonywania powierzonych mu zadań ze szczególną starannością i bezstronnością, zgodnie z zasadami wynikającymi z przepisów prawa;

[...]

3) doskonalenia kwalifikacji zawodowych.

Ustawowe zobowiązanie tłumaczy przysięgłych do zachowania „szczególnej staranności” przy świadczeniu usług tłumaczeniowych, pisemnych i ustnych, nakłada na tłumacza przysięgłego obowiązek dostarczania translatów wysokiej jakości - przepisy krajowe korespondują tutaj z prawem wspólnotowym. Natomiast gwarancją zapewnienia wysokiej jakości ma być m.in. obowiązek nałożony przez ustawę na tłumaczy przysięgłych do ustawicznego podnoszenia kwalifikacji zawodowych ${ }^{4}$.

${ }^{3} \mathrm{~W}$ przepisach prawa polskiego nigdy wcześniej nie stosowano wyrażenia „szczególnie ważne przyczyny”, a jedynie „ważne przyczyny” (por. Dostatni 2005: 97), które rozumiane są jako przyczyny trudne do przezwyciężenia. Stąd można założyć, że sformułowanie „szczególnie ważne przyczyny" dotyczy przyczyn niemożliwych do przezwyciężenia.

${ }^{4}$ Zobowiązanie to obejmuje nie tylko kształcenie w zakresie języka obcego i rozwijanie kompetencji translatorskiej (tłumaczenie pisemne i ustne), ale również ustawiczne kształcenie w zakresie przepisów prawa, reguł wykonywania zawodu oraz wszelkich innych (prawnych) aspektów, mających znaczenie dla wykonywania zawodu tłumacza przysięgłego (Cieślik et. al 2010: 49). 
Uregulowanie obowiązków tłumaczy przysięgłych $\mathrm{w}$ randze ustawy świadczy o ich wielkim znaczeniu; dodatkowym potwierdzeniem jest fakt, że w przypadku ich niewykonywania (a więc w przypadku niezachowania szczególnej staranności w działalności tłumaczeniowej, niewykonania zlecenia na żądanie organów państwowych, zaniedbania doskonalenia kwalifikacji) tłumacz przysięgły podlega odpowiedzialności zawodowej (art. 21 ust. 1). Naruszenie Ustawy prowadzi do wszczęcia postępowania dyscyplinarnego (art. 24 ust. 1 i 2), w wyniku którego na tłumacza przysięgłego może zostać nałożona kara dyscyplinarna (art. 21 ust. 2) ${ }^{5}$. Jej najcięższa forma, pozbawienie tłumacza prawa wykonywania zawodu, skutkuje natychmiastowym skreśleniem z listy (art. 27).

\section{Tłumaczenie sądowe w Polsce w świetle przepisów prawa}

\subsection{Rynek tłumaczenia sądowego}

Fakt: Polscy tłumacze przysięgli to "self-made professionals” (Kierzkowska 1992: 17). Spośród całkowitej liczby tłumaczy przysięgłych w Polsce, wynoszącej obecnie $10841^{6}$, z czego prawie $83 \%$ to tłumacze tylko czterech języków: niemieckiego, angielskiego, rosyjskiego i francuskiego, zaledwie ułamek, a dokładnie 7,5\%, zostało ustanowionych zgodnie z wymogami Ustawy. Wynika z tego, że 10000 polskich tłumaczy przysięgłych została ustanowiona w erze przedustawowej (por. Cieślik et al. 2010: 85), a mianowicie na mocy przepisów rozporządzenia Ministra Sprawiedliwości z dnia 8 czerwca $1987 \mathrm{r}$. w sprawie biegłych sądowych i tłumaczy przysięgłych (Dz. U. nr 18 poz. 112).

Fakt ten ma wielkie znaczenie i dalekosiężne konsekwencje (por. 3.3). Ustawodawca do wykonywania zawodu tłumacza przysięgłego dopuszczał wówczas tylko i wyłącznie absolwentów studiów filologicznych lub lingwistycznych, co oznaczało, że umiejętność tłumaczenia pisemnego i ustnego została zrównoważona ze znajomością języka obcego. Tymczasem programy wymienionych studiów nie przewidywały nauczania żadnych przedmiotów translatologicznych, a studia tłumaczeniowe w Polsce nie istniały (por.

${ }^{5}$ Za niestawiennictwo na wezwanie sądu tłumacz przysięgły może być dodatkowo pociągnięty do odpowiedzialności karnej zgodnie z art $285 \mathrm{kpk}$.

${ }^{6}$ Lista tłumaczy przysięgłych http://bip.ms.gov.pl/pl/rejestry-i-ewidencje/tlumacze-przysiegli/lista-tlumaczy-przysieglych/search.html (dostęp: 5 lipca 2015 r.). 
Kierzkowska 2007: 130-131)7 . Dlatego większość polskich praktykujących tłumaczy przysięgłych, ówcześni absolwenci filologii i lingwistyki, nie może formalnie udokumentować zdobycia kwalifikacji translatorskich. Ponieważ nie otrzymali oni żadnego przygotowania do wykonywania zawodu, byli zmuszeni wypracować sobie samodzielnie odpowiednie narzędzia i wytyczne (Kierzkowska 2007: 130).

Ustawa o zawodzie tłumacza przysięgłego, która weszła w życie 27 stycznia 2005 r. zmieniła dostęp do wykonywania zawodu tłumacza przysięgłego, wprowadzając wysokie wymagania oraz przede wszystkim egzamin państwowy dla kandydatów, mający weryfikować ich umiejętności zarówno w zakresie tłumaczenia pisemnego, jak i ustnego ${ }^{8}$. Dopuszczając do wykonywania zawodu tłumacza przysięgłego tylko osoby o potwierdzonych wysokich kwalifikacjach i odpowiednich kompetencjach translatorskich, Polska spełnia wymogi dyrektywy unijnej, a nowo ustanowieni tłumacze odpowiadają jej wymaganiom. Inaczej jednak przedstawia się sytuacja tłumaczy ustanowionych na mocy wspomnianego rozporządzenia, którzy - mimo że w większości przypadków nie spełniają ani wymogów polskiej Ustawy, ani przepisów wspólnotowych - zostali automatycznie i bezwarunkowo wpisani na listę tłumaczy przysięgłych na czas nieokreślony.

Fakt: Zapotrzebowanie sądów na usługi wykwalifikowanych tłumaczy sądowych nie zawsze może być zaspokojone.

Badanie ankietowe przeprowadzone wśród polskich sądów (por. Nartowska 2011) wykazało, że około połowa wszystkich sądów okręgowych w Polsce wzywa tłumacza stosunkowo często, od minimum 1 raz w miesiącu do kilku razy w tygodniu ${ }^{9}$ (najwięcej SO w Warszawie, Suwałkach, Poznaniu i Gdańsku). Analiza badanej próby sądów rejonowych pozwala przypuszczać, ze udział tłumaczy w postępowaniach toczących się w sądach rejonowych jest wyższy niż w sądach okręgowych. Sądy rejonowe znacznie częściej podawały, że powołują tłumaczy kilkadziesiąt, a nawet wielokrotnie kilkaset razy

7 Pierwsze studia podyplomowe dla tłumaczy prawniczych i sądowych zostały utworzone dopiero w 1998 r. przy Instytucie Lingwistyki Stosowanej Uniwersytetu Warszawskiego (zob. Kierzkowska 2000).

${ }^{8}$ Egzamin stanowi skuteczną barierę wejścia na rynek: w ciągu ostatnich 4,5 lat, od września 2011 r., liczba tłumaczy przysięgłych zwiększyła się z 10463 do 10841, a więc uprawnienia uzyskały tylko 378 osoby (por. Nartowska 2011: 22).

9 Analiza opiera się w znacznej mierze na danych szacunkowych ze względu na brak prowadzenia ewidencji rozpraw $z$ udziałem tłumacza przez polskie sądy. Ponieważ jednak dyrektywa 2010/64/UE zobowiązuje państwa członkowskie do prowadzenia rejestru wszelkich postępowań z udziałem tłumacza (art. 7), możliwe będzie ponowne przeprowadzenie dokładnych badań rynku oraz zweryfikowanie wysuniętych hipotez. 
$\mathrm{w}$ roku. $\mathrm{Z}$ analizy wynika również, że tłumacze sądowi potrzebni są $\mathrm{w}$ różnych wydziałach, przede wszystkim w wydziale karnym, ale również cywilnym, gospodarczym, pracy, ubezpieczeń itd.

Badane sądy wymieniły w sumie 34 różne języki, na które wystąiło zapotrzebowanie w związku z toczącymi się postępowaniami. Najczęściej podawane były popularne języki europejskie, takie jak niemiecki, angielski, rosyjski, włoski, francuski i ukraiński, w przypadku których potrzeby sądów korespondują z największą liczbą ustanowionych tłumaczy przysięgłych. W sądach występują jednak też języki, dla których liczba tłumaczy w całym kraju wynosi już tylko kilkadziesiąt lub kilkanaście osób, m.in. język rumuński (34), wietnamski (19), arabski (57) czy litewski w Suwałkach (43, w województwie podlaskim 18). Poza tym istnieje zapotrzebowanie na szereg innych języków (por. Nartowska 2011: 26-27, Mendel 2011: 6-7), dla których w całej Polsce ustanowionych jest co najwyżej kilku tłumaczy albo tłumaczy przysięgłych nie ma wcale (np. języka urdu $)^{10}$. W przypadku tych języków popyt sądów na usługi wykwalifikowanych tłumaczy pisemnych i ustnych nie może być wystarczająco zaspokojony (por. 3.2 i 3.3).

\subsection{Kształcenie tłumaczy sądowych}

Fakt: Brakuje uniwersyteckiej oferty kształcenia tłumaczy sądowych w Polsce.

Chociaż od transformacji ustrojowej w Polsce sytuacja kształcenia tłumaczy w ogóle znacznie się poprawiła, nadal brak jest studiów uniwersyteckich czy programów szkoleniowych dla tłumaczy sądowych. Studia filologiczne, które stopniowo zaczęły wprowadzać w minimalnym zakresie moduły kształcenia w zakresie translatoryki, nie przygotowują absolwentów do wykonywania zawodu tłumacza ${ }^{11}$, one zasadniczo mają inne cele. Ale nawet ukończenie studiów translatorycznych, do których w Polsce najbardziej zbliżone jest kształcenie tłumaczy $w$ ramach studiów lingwistycznych, naj-

${ }^{10}$ Daje się jednak zauważyć pozytywny trend po stronie podaży: Jeszcze w roku 2011 nie było w całym kraju tłumaczy przysięgłych języków mongolskiego, ormiańskiego i gruzińskiego (por. Nartowska 2011: 25-27), obecnie jest ustanowiony 1 tłumacz języka mongolskiego i po 4 osoby w przypadku dwóch ostatnich języków. W stosunku do roku 2011 liczba języków, dla których ustanowieni są obecnie tłumacze przysięgli w Polsce, zwiększyła się o 5, z 46 do 51.

11 O niewystarczającym przygotowaniu filologów do wykonywania zawodu tłumacza Kierzkowska 2003, Kubacki 2012, Żmudzki 2010 cyt. za Błaszkowska 2014. Świadczy o tym również bardzo niska kwota sukcesu wśród kandydatów zdających państwowy egzamin na tłumacza przysięgłego (por. Kubacki 2012: 198). 
częściej jako uzupełniające studia magisterskie (przykłady zob. Błaszkowska 2014, Jopek-Bosiacka 2014, Tyupa 2014), nie wystarcza, aby wykonywać zawód tłumacza sądowego (Kadrić 2009: 219). Tłumacz sądowy musi bowiem nabyć i rozwinąć specyficzne kompetencje i umiejętności, których programy studiów translatorycznych obecnie nie obejmują, a moduły dotyczące kształcenia tłumaczy sądowych, przede wszystkim w zakresie tłumaczenia ustnego, praktycznie nie istnieją ${ }^{12}$.

Ustawa o zawodzie tłumacza przysięgłego przyniosła ze sobą diametralne zmiany w kształceniu przyszłych tłumaczy i spowodowała powstanie w ostatnim 10-leciu w całej Polsce niezliczonych studiów podyplomowych w zakresie translatoryki ${ }^{13}$. Studia te umożliwiają wprawdzie zdobycie podstawowych kwalifikacji translatorskich osobom, które opanowały język obcy, zarówno absolwentom studiów niejęzykowych, jak również filologom, i które chcą rozpocząć karierę tłumacza, ich oferta jednak rzadko skierowana jest do tłumaczy przysięgłych lub sądowych. Poszczególne jednostki albo kierują ofertę osobno do tłumaczy pisemnych (tekstów specjalistycznych, tekstów literackich) lub tłumaczy ustnych (konferencyjnych) (np. Katedra UNESCO Uniwersytetu Jagiellońskiego), albo reklamują wprawdzie przygotowanie praktyczne do zawodu tłumacza przysięgłego, w praktyce jednak kształcenie w nich odbywa się w znacznej mierze jednotorowo, koncentrując się na umiejętności tłumaczenia pisemnego (specjalistycznego) (por. Kubacki 2012: 271 i nast.). Wyjątek stanowi dwusemestralne Interdyscyplinarne Podyplomowe Studium Kształcenia Tłumaczy (IPSKT) w Instytucie Lingwistyki Uniwersytetu Warszawskiego ${ }^{14}$, którego celem jest nabycie umiejętności w zakresie tłumaczenia prawniczego i sądowego oraz przygotowanie do wykonywania zawodu tłumacza przysięgłego. Kurs obejmuje moduł metodologia przekładu sądowego oraz warsztaty przekładowe (pisemne i ustne). Studia przeznaczone są dla tłumaczy języków angielskiego, francuskiego, hiszpańskiego, niemieckiego, rosyjskiego i włoskiego ${ }^{15}$. 2014a).

${ }^{12}$ W konsekwencji tłumacze są zmuszeni improwizować na sali rozpraw (por. Nartowska

${ }^{13}$ Uczelnie kształcące tłumaczy http://www.tepis.org.pl/index.php/linki/uczelnie-ksztalcace-tlumaczy (dostęp: 5 lipca 2015 r.).

${ }^{14}$ IPSKT https://www.ils.uw.edu.pl/80.html (dostęp: 5 lipca 2015 r.).

${ }_{15}$ Ponadto istnieje oferta przygotowująca kandydatów do egzaminu dla tłumaczy poszczególnych języków, np. Studia podyplomowe kształcenia tłumaczy języka niemieckiego Uniwersytetu Adama Mickiewicza w Poznaniu, Studium podyplomowe przygotowujące do egzaminu na tłumacza przysięgłego języka angielskiego w Wyższej Szkole Lingwistycznej w Częstochowie czy Szkolenie dla kandydatów na tłumaczy przysięgłych języka rosyjskiego na Uniwersytecie Warmińsko-Mazurskim w Olsztynie. 
Warta podkreślenia jest również oferta szkoleniowa TEPISU skierowana zarówno do praktykujących, już ustanowionych tłumaczy przysięgłych, tłumaczy powoływanych do sądu ad hoc, jak również kandydatów zainteresowanych wykonywaniem zawodu tłumacza przysięgłego, w postaci Laboratorium Tłumacza Przysięgłego ${ }^{16}$. Celem tego 9-miesięcznego kursu jest przekazanie wiedzy oraz praktycznych umiejętności zarówno tłumaczenia pisemnego specjalistycznego, jak i tłumaczenia ustnego ze szczególnym uwzględnieniem zakresu prawniczego, sądowego i ekonomicznego, stąd bardzo praktyczny charakter kursu. Laboratorium zawiera moduł tłumaczenie ustne sądowe. Początkowo kurs odbywał się tylko w języku polskim, dlatego stanowił atrakcyjną ofertę kształcenia zwłaszcza dla uczestników pracujących w językach, dla których nie ma przewidzianych studiów uniwersyteckich ani podyplomowych. Obecnie zajęcia prowadzone są w językach: angielskim, francuskim, niemieckim, rosyjskim i włoskim.

Skierowanie oferty studiów oraz szkoleń tylko do wąskiej grupy tłumaczy, mianowicie najpopularniejszych języków europejskich, i równoczesne zupełne zaniedbanie tłumaczy kilkudziesięciu innych języków, wydaje się dość problematyczne. Sytuacja ta powoduje również niezadowolenie samych tłumaczy przysięgłych (por. Mendel 2011: 34 i nast.). Znacznym problemem jest też fakt, ze studia podyplomowe i kursy szkoleniowe prowadzone są przez tłumaczy praktyków i mają charakter wyłącznie praktyczny, a rzadko opierają się na teorii (translatologii, tłumaczenia sądowego). Brakuje również modułów budzących świadomość co do roli tłumacza sądowego, zachowania na sali rozpraw lub podstaw etyki zawodowej. W wyniku tej sytuacji praktykującym tłumaczom (sądowym) brakuje fundamentu, na którym mogliby oprzeć swoją działalność tłumaczeniową (w sądzie).

\subsection{Praktyka tłumaczenia sądowego w Polsce}

Fakt: Sądy w Polsce mają trudności w znalezieniu tłumacza na rozprawę.

Mimo że w Polsce jest ponad 10800 tłumaczy przysięgłych, sądy oraz inne organa państwowe mają ogromne problemy ze znalezieniem tłumacza na rozprawę. Świadczą o tym m.in. wypowiedzi pracowników wymiaru sprawiedliwości: „[tłumacze] albo odmawiali przyjazdu do MIEJSCOWOŚĆ albo po wyrażeniu zgody na udział w czynnościach rezygnowali. Ustala-

${ }^{16}$ Laboratorium Tłumacza Przysięgłego http://www. tepis.org.pl/ksztalcenie/tepis/lktps-ii. pdf (dostęp: 1 listopada 2013 r.). 
niem tłumacza musiał się zajmować osobiście prokurator niemal błagając telefonicznie tłumacza o szybki przyjazd” (Mendel 2011: 7) oraz „większość tłumaczy nie chciała podjąć się tłumaczenia sprawy o wypadek drogowy śmiertelny" (Nartowska 2014b: 445). W tym ostatnim przypadku sędzia sądu rejonowego zmuszony jest, po wielokrotnej odmowie przez tłumaczy przysięgłych, wzywać nauczycieli języka obcego (sic!). Paradoksalny jest fakt, że powyższa sytuacja dotyczyła zapotrzebowania sądu na usługi tłumacza języka niemieckiego, których w Polsce jest najwięcej (3832) ${ }^{17}$; znalezienie tłumacza w przypadku języków rzadszych i rzadkich jest jeszcze trudniejsze i zmusza organa do powoływania tłumaczy ad hoc o niepotwierdzonych kwalifikacjach (por. Mendel 2011: 5-7). Sytuacja ta spowodowana jest poniższym:

Fakt: Tłumacze przysięgli niechętnie pracują w sądach.

Mimo że można założyć, iż osoba podejmująca decyzję o wyborze zawodu tłumacza przysięgłego dokonuje jej świadomie, a więc zdaje sobie sprawę, że musi ona wypełniać zadania zarówno tłumacza pisemnego, jak i tłumacza ustnego, mimo że ustawa zobowiązuje tłumaczy przysięgłych do pracy na rzecz sądu oraz mimo możliwych sankcji, tłumacze przysięgli nagminnie odmawiają wykonania zleceń na rzecz sądu, „lepiej jeszcze: stosują oni wszystkie możliwe środki, aby właśnie owych tłumaczeń w ogóle nie otrzymać" (Kuipers 2003: 111, tłum. K.N.) ${ }^{18}$. Jest wiele przyczyn tego stanu rzeczy:

Fakt: Tłumacze nie czują się wystarczająco kompetentni w zakresie tłumaczenia ustnego (sądowego) (por. 3.1 i 3.2).

Dawniej działalność tłumacza przysięgłego polegała głównie na tłumaczeniu pisemnym, dziś natomiast praca na rzecz organów, w tym sądów, należy do codzienności tego zawodu. Tłumacze, ustanowieni zarówno na mocy rozporządzeń, jak i na mocy Ustawy, którzy nie otrzymali formalnego wykształcenia, mają świadomość, że nie są wystarczająco przygotowani do pracy w sądzie i brakuje im kompetencji translatorskiej, ale także doświadczenia. Obrazuje to wypowiedź tłumacza: „[Na studiach] z tłumaczeń nie było absolutnie nic. (...) jak mam tłumaczyć ustnie, to jest to dla mnie problem, z tego tytułu właśnie, że nie mam takiego doświadczenia" (Nartowska 2014b:

17 Podobnie następujące słowa: „W przypadku języka niemieckiego dopiero dwudziesta osoba z listy tłumaczy przysięgłych zgodziła się sporządzić tłumaczenie” (Mendel 2011: 7).

18 Również pracownicy wymiaru sprawiedliwości wskazują na wymówki tłumaczy: „Wszyscy tłumacze przysięgli i tłumacze odmówili udziału w czynnościach tłumacząc się przebywaniem na urlopach, przebywaniem poza miejscem zamieszkania” (Mendel 2011: 7). 
371-372 $)^{19}$. Tłumacze obawiają się wobec tego wiążącej się z tłumaczeniem sądowym odpowiedzialności.

Fakt: Stawki za tłumaczenie ustne na rzecz organów są od lat zaniżone.

Stawki ustanowione na mocy rozporządzenia w sprawie wynagrodzenia za czynności tłumacza przysięgłego (Dz. U. nr 15 poz. 131) są nie do zaakceptowania i stanowią jeden $\mathrm{z}$ głównych powodów niechęci tłumaczy przysięgłych do pracy na rzecz organów (por. Mendel 2011: 24-25). Wynagrodzenie ministerialne w żaden sposób nie jest odzwierciedleniem ani wysokich kompetencji niezbędnych tłumaczowi sądowemu, ani też odpowiedzialności, jaka na tłumaczu spoczywa. Ponadto nie stanowi ono źródła motywacji dla tłumaczy do podjęcia pracy na rzecz organów czy w sądzie, często jest to działanie wręcz nierentowne, a tym bardziej do przygotowywania się do rozprawy. Problem dodatkowo potęguje opieszałość sądów w regulowaniu należności.

\subsection{Współpraca tłumaczy sądowych z organami}

Fakt: Nie wszyscy przedstawiciele wymiaru sprawiedliwości rozumieją specyfikę pracy tłumacza.

Badania przeprowadzone przez Mendel (2011) wśród przedstawicieli instytucji państwowych nie są wprawdzie reprezentatywne ${ }^{20}$ i nie zostały poddane obszernej analizie naukowej, dostarczają jednak kilku wskazówek na temat obecnego stanu współpracy organów państwowych z tłumaczami. $\mathrm{Z}$ ankiety wynika, że osoby współpracujące $\mathrm{z}$ tłumaczami nie zawsze zdają sobie sprawę $\mathrm{z}$ charakteru pracy tłumacza sądowego, co w konsekwencji może negatywnie wpływać na działania tłumacza ${ }^{21}$. Przykładowo, mimo że większość ankietowanych udziela tłumaczowi informacji dotyczących prowadzonego postępowania karnego, takich jak podstawa prawna, czas, miejsce, okoliczności udzielenia czynu, zdarzają się sytuacje, kiedy tłumacz tych danych nie otrzymuje (Mendel 2011: 9-10). Argumentacja przedstawicieli instytucji, że informacje te nie mają znaczenia albo nie są niezbędne do przetłumaczenia ustnego i zapewnienia jakości translatu („Do tłumaczenia nie

19 Problem stanowi również obszerna terminologia, jaką tłumacz sądowy musi opanować w stopniu umożliwiającym mu jej szybkie zastosowanie na sali rozpraw: „Tłumacz (...) musi się znać na wszystkim: musisz się znać na medycynie, na technice, na właśnie gospodarce (...) na prawie (...)” (Nartowska 2014: 380).

${ }^{20} \mathrm{~W}$ ankiecie wzięło udział 351 przedstawicieli wymiaru sprawiedliwości.

21 Negatywny wpływ brakującego doświadczenia prawników we współpracy z tłumaczami na działanie tłumacza na sali rozpraw potwierdza również Nartowska (2014). 
jest to potrzebne”, „Nie uważam, aby było to konieczne do wykonania powierzonego mu zadania... Okoliczności czynu nie mają tu większego znaczenia, albowiem tłumacz albo dane słowo czy wyrażenie zna, albo nie”) świadczą o tym, że prawnicy postrzegają język jako kod, za pomocą którego zakodowane są treści. Zadanie tłumacza polega zatem na automatycznym przełączaniu między dwoma kodami, znajdującymi się względem siebie w stosunku jeden do jednego, a więc bez żadnej straty merytorycznej czy formalnej (por. Morris 1995) ${ }^{22}$. Natomiast nieudzielanie tłumaczowi informacji lub zgody na wgląd do akt ze względu na jego bezstronność lub zachowanie tajemnicy (Mendel 2011: 10-13) wynika z nieznajomości ustawowych obowiązków tłumaczy przez przedstawicieli wymiaru sprawiedliwości.

Niektórzy ankietowani zwrócili uwagę, że nie udzielają oni wymienionych informacji lub nie zapewniają wglądu do akt, ponieważ to tłumacze nie wykazują zainteresowania ich otrzymaniem: „...sami tłumacze nigdy (nie spotkałam się z takim żądaniem przez 20 lat pracy) nie zgłaszają takich wniosków. Gdyby tłumacz prosił o udostępnienie akt, np. w sekretariacie, wydałabym na to zgodę" (Mendel 2011: 12) ${ }^{23}$.

Znaczna większość ankietowanych prawników podała również, że po odczytaniu pisma sądowego, przekazuje go tłumaczowi w celu przetłumaczenia a vista (Mendel 2011: 13), tylko nieliczni są zdania, że nie ma takiej potrzeby lub tego nie robią.

\subsection{Jakość ttumaczenia w sądzie}

Fakt: Jakość tłumaczenia sądowego bywa niewystarczająca.

Na temat jakości tłumaczenia sądowego w Polsce nie ma badań na szeroką skalę. Z analizy przypadku dotyczącej roli tłumacza sądowego w polskim postępowaniu karnym (Nartowska 2014b), która nie pozwala wprawdzie na wyciągnięcie ogólnych wniosków, wynika jednak, że jakość tłumaczenia w sądzie bywa zastraszająco niska. Problem ten obrazuje poniższy przykład tłumaczenia aktu oskarżenia:

${ }^{22} \mathrm{Z}$ perspektywy prawników proces tłumaczeniowy umożliwia sądowi efektywne funkcjonowanie, jak gdyby był to kontekst monolingwalny. Przekonanie że wszystko, co jest powiedziane w języku obcym, może zostać „przełączone” na język postępowania i w nim pełnić funkcję oryginału, Morris (1995: 30-31) nazywa fikcją prawną.

${ }^{23}$ Większość ankietowanych tłumaczy w tym samym badaniu podała, że prosi o udzielenie informacji (Mendel 2011: 30-31), badana próba była jednak zbyt mała (zaledwie 53 osoby), by zapewnić reprezentatywność. 
Sędzia: • . Y Yhm. $((1,6 s))$ Dobrze, w takim razie proszę o odczytanie aktu oskarżenia.

Tłumacz: Also jetzt wird • Anklageschrift... [A więc teraz będzie • akt oskarżenia...] Prokurator: Oskarżam Karla Fischer • o to, żee: • • w dniu DZIEŃ MIESIĄC ROK T: My możem/ możemy usiąść?

((szepta)) Wir können jetzt sitzen. [Możemy teraz siedzieć.]

Pr: w miejscowości NAZWA, gmina NAZWA $((1,1 s))$ naruszył zasady bezpieczeństwa w ruchu drogowym

$\mathrm{T}$ : $((2,0 \mathrm{~s}))$ Und jetzt ist diese... $((1,6 \mathrm{~s}))[((2,0 s))$ A teraz jest ten... $((1,6 s))]$

diese/ $\bullet$ das hier $(())$ vorgelesen $\bullet \bullet(())$ und das. [ten $/ \bullet$ to tutaj $(())$ czytane na głos

- (()) i to.] Nie dostał yyy...?

Pr: w ten sposób, że kierując samochodem osobowym marki MODEL POJAZDU

Obrońca: •• Skróconą wersję.

Pr: NUMER REJESTRACJI • • • na prostym odcinku drogi nie zachował należytej

T: Das ist das hier. [To jest to tutaj.]

Pr: ostrożności, podczas wykonywania manewru wyprzedzania najechał na

Przykład ten pokazuje, że zadanie translatorskie przerasta tłumacza, który usiłuje zachować twarz, stosując różne strategie „nietłumaczenia”. Najpierw komentuje przebieg wydarzeń na sali rozpraw, następnie szuka odczytywanego fragmentu $\mathrm{w}$ dokumentach oskarżonego, a na koniec zastępuje tłumaczenie wskazaniem oskarżonemu danego ustępu tekstu. W ten sposób oskarżony pozbawiony zostaje możliwości udziału w rozprawie, $\mathrm{w}$ akcie odczytywanego oskarżenia i nie jest w stanie w pełni korzystać ze swojego prawa do obrony. Oznacza to, że oskarżonemu nie zostało zapewnione prawo do rzetelnego procesu, a jego naruszenie może być dochodzone sądownie. Zatem w przypadku złożenia skargi do Europejskiego Trybunału Praw Człowieka Polska mogłaby zostać ukarana wyrokiem (por. Kabelka 1992: 25).

Niewystarczająca bądź niska jakość tłumaczenia ma też inne, dalekosiężne konsekwencje: po pierwsze może wiązać się z koniecznością odroczenia rozprawy oraz wezwaniem innego tłumacza, co powoduje dodatkowe koszty i prowadzi do nieefektywności. Po drugie stanowi podstawę złożenia skargi przez oskarżonego zgodnie z przepisami dyrektyw 2010/64/UE. Natomiast zgodnie z polską Ustawą tłumaczowi, który nie spełnia ani wymogów prawa krajowego, ani wspólnotowego, grożą środki dyscyplinarne.

Oczywiście, omawiany przykład nie pozwala na stwierdzenie, ze problem niskiej jakości tłumaczeń dotyczy wszystkich tłumaczy przysięgłych w Polsce albo że dotyczy on tylko i wyłącznie tłumaczy ustanowionych przed wejściem Ustawy w życie, a nowo ustanowionych nie. Niewątpliwie niepo- 
kojące jest jednak wystąpienie już pojedynczych przypadków tego rodzaju praktyk, które mają miejsce ze względu na fakt, że tłumacze świadomi swoich ustawowych obowiązków, podejmują się pracy na rzecz sądu, mimo braku przygotowania.

Badania empiryczne (Kadrić 2009, Nartowska 2014b, w druku) dowodzą ponadto, że dla jakości tłumaczenia i pracy w sądzie niezbędne jest wykształcenie poprawnej tożsamości tłumacza co do własnej roli jako tłumacza sądowego. Jeżeli tłumacz nie rozwinie właściwej świadomości co do swojej roli jako eksperta do spraw komunikacji międzykulturowej (lub rozwinie błędną tożsamość), swoim działaniem może negatywnie wpływać na interakcję sądową, na przebieg procesu i na współpracę z prawnikami.

\section{Postulaty zmian}

Powyższa diagnoza stanu faktycznego tłumaczenia sądowego oraz sytuacja tłumaczy sądowych w Polsce pozwalają na wysunięcie następujących postulatów:

\subsection{Weryfikacja kompetencji ustanowionych tłumaczy przysięgłych}

Aby spełnić wymogi prawa wspólnotowego i zapewnić wysoką jakość tłumaczenia wyłącznie przez wysoce wykwalifikowanych tłumaczy, należałoby zweryfikować umiejętności ustanowionych tłumaczy przysięgłych. Rozwiązanie takie zastosowano m.in. w Austrii: chociaż ustawa dotycząca zawodu tłumacza przysięgłego obowiązuje od 1975 roku$^{24}$, egzamin dla kandydatów na tłumaczy przysięgłych (tzw. certyfikacja) został wprowadzony dopiero w 1998 roku. Tłumacze ustanowieni przed nowelizacją ustawy, podobnie jak w Polsce, zostali automatycznie wpisani na listę tłumaczy przysięgłych, z tą jednak różnicą, że na czas określony 10 lat (por. Soukup-Unterweger 2003). Po upływie tego okresu każdy tłumacz chcący pozostać na liście tłumaczy przysięgłych musiał poddać się weryfikacji: 1. swoich kompetencji 2. aktywności zawodowej oraz 3. rozwoju zawodowego. Obowiązkowi recertyfikacji podlegają naturalnie również nowo ustanowieni tłumacze przysięgli (po zdanym egzaminie), najpierw po okresie 5 lat, a następnie po każdych kolejnych 10 latach, pod warunkiem spełnienia powyższych wymogów (podobnie jest

${ }^{24}$ Sachverständigen- und Dolmetschergesetz vom 19. Feber 1975 (BGBl. Nr. 137/1975). 
np. w Grecji i Holandii). Wprowadzenie egzaminu jako bariery wejścia, ale przede wszystkim obowiązek poddawania weryfikacji własnych umiejętności, pozwoliły zagwarantować, że na rynku zostali tylko tacy tłumacze sądowi, którzy spełniają stawiane im wymagania i są w stanie zapewnić wysoką jakość tłumaczenia.

Polska w tej chwili nie spełnia wymogów prawa wspólnotowego, mimo obowiązku nałożonego na państwa członkowskie przez przepisy dyrektywy. Dlatego weryfikacja umiejętności ustanowionych tłumaczy przysięgłych zapewniłaby, że na liście pozostaliby tłumacze o szczególnie wysokich kwalifikacjach. Tylko takim tłumaczom powinien być powierzony zawód tłumacza przysięgłego, który jest zawodem zaufania publicznego. Natomiast usunięcie tłumaczy nieaktywnych $\mathrm{z}$ listy tłumaczy przysięgłych poprzez ich zawieszenie nie jest rozwiązaniem, ponieważ nie zmienia w żaden sposób obecnej sytuacji. Dotyczy ono bowiem tłumaczy, którzy - ze względu na swoją nieaktywność nie podejmują się pracy w sądzie, a nie obejmuje tłumaczy aktywnych, którzy, nie mając ani przygotowania, ani doświadczenia, pracują na rzecz organów. Dzięki weryfikacji umiejętności możliwe byłoby wyeliminowanie problemu niskiej jakości tłumaczeń w sądzie oraz nagminnych odmów wykonywania zleceń na rzecz organów. Takie rozwiązanie uzasadniałoby poza tym walkę o podniesienie stawek ministerialnych, które byłyby odzwierciedleniem faktycznych kompetencji oraz odpowiedzialności tłumaczy przysięgłych. Dodatkową korzyścią wprowadzenia tych zmian byłaby konsolidacja środowiska i zlikwidowanie podziału, jaki istnieje teraz w Polsce, na równych i równiejszych.

\subsection{Zmiany w kształceniu tłumaczy przysięgłych}

Powszechne wydaje się założenie, ze nie ma tłumaczenia sądowego w Polsce, stąd może ono nie istnieć w kształceniu tłumaczy lub zajmować tam jedynie marginalne miejsce. Problemy pojawiają się dopiero, gdy tłumacz przysięgły zostaje wezwany po raz pierwszy do sądu i nawet nie wie, gdzie ma zajęć miejsce, nie mówiąc już o wypełnieniu swoich ustawowych zadań. Dlatego niezbędne są zmiany w systemie kształcenia tłumaczy sądowych w Polsce, które obowiązkowo muszą kształcić dwutorowo - w zakresie tłumaczenia pisemnego i w zakresie tłumaczenia ustnego.

Nieodzowne jest, aby zarówno studia uniwersyteckie, jak i kursy dla tłumaczy (sądowych) miały charakter teoretyczno-praktyczny. Po pierwsze bez teorii nie ma podstaw do wykonywania zawodu, a po drugie zajęcia praktyczne ani nie przewidzą, ani nie obejmą wszystkich możliwych scenariuszy 
w sądzie. Opanowanie technik tłumaczeniowych oraz podstawowa znajomość terminologii różnych dziedzin nie wystarczą do pracy na rzecz organów, niezbędne jest swobodne poruszanie się w kontekście instytucjonalnym, znajomość przepisów prawa, znajomość praktyk procesowych, ról uczestników oraz przebiegu procesu oraz wykształcenie szeregu cech osobowości, jak pewność siebie, asertywność, umiejętność radzenia sobie ze stresem i emocjami. Dlatego część praktyczna zajęć powinna mieć formę możliwie zbliżoną do rzeczywistości, np. w postaci odgrywania ról i dyskusji, a nawet grupowych wizyt w sądzie.

Niezbędne w kształceniu tłumaczy sądowych jest rozwinięcie u tłumaczy świadomości co do ich roli jako tłumacza sądowego i eksperta do spraw komunikacji międzykulturowej, który ponosi odpowiedzialność za zrozumienie i bycie zrozumianym. Wiąże się z tym znajomość praw i obowiązków na sali sądowej, zasad etyki zawodowej i ich zastosowania w praktyce, a także właściwe zachowanie na sali rozpraw: to tłumacz musi wiedzieć, gdzie zająć miejsce, by optymalnie wykonać swoje zadanie, a w razie potrzeby zmienić miejsce podczas rozprawy; to tłumacz musi wiedzieć, że potrzebuje tekstu do przetłumaczenia go a vista i nic nie stoi na przeszkodzie, by o ten tekst poprosić. Nie można oczekiwać, ze prawnicy będą znali zadania tłumacza i będą wychodzili im na przeciw, od tłumaczy też nie oczekuje się znajomości obowiązków adwokata czy prokuratora.

Ponieważ studia uniwersyteckie w Polsce skierowane są do tłumaczy zaledwie kilku popularnych języków, a zapotrzebowanie sądów na tłumaczy rzadszych i rzadkich języków rośnie, wiodąca rola w kształceniu tłumaczy sądowych powinna przypaść organizacji zawodowej TEPIS. Priorytetem dla TEPISU powinno być najpierw dotarcie do 9800 (sic!) tłumaczy przysięgłych w Polsce nie będących członkami zrzeszonymi (liczba ta potwierdza fakt, że tłumacze przysięgli nie utożsamiają się z własną rolą), a następnie skierowaniem do nich specjalnej oferty szkoleń. Organizacja kieruje warsztaty często do nowoustanowionych, „niedoświadczonych” tłumaczy przysięgłych, którzy swoje kompetencje potwierdzili zdanym egzaminem, a brakuje szkoleń dla tłumaczy, którzy nigdy nie poddali swoich umiejętności weryfikacji. Rolą TEPISU jest też krzewienie właściwej postawy wobec zawodu oraz budzenie świadomości co do własnej roli. Nagląca jest potrzeba stworzenia oferty szkoleniowej bez podziału na sekcje językowe ${ }^{25}$, aby umożliwić udział jak najwięk-

${ }^{25}$ Forma tego rodzaju szkoleń dla tłumaczy jest wyraźnie zalecana przez Forum Refleksji jako ścieżka kształcenia tłumaczy prawniczych (pisemnych i ustnych) (European Commission, DG Interpretation 2009). 
szej liczbie uczestników. Dobry przykład tego rodzaju warsztatów dostarcza ponownie Austria (por. Kadrić 2005). Alternatywą dla kursów oferowanych tylko w dużych miastach są nowe media, a przede wszystkim możliwość zastosowania Internetu i techniki e-learning, umożliwiając dostęp szerokiemu gronu zainteresowanych tłumaczy.

Dostosowując ofertę kształcenia do potrzeb rynku, Polska będzie w stanie zapewnić wysokie kwalifikacje (przyszłych) tłumaczy sądowych, spełniając tym samym wymogi prawa krajowego i wspólnotowego. Nie wydaje się natomiast właściwym rozwiązaniem postulowane w środowisku rozdzielenie zawodu tłumacza przysięgłego na tłumacza pisemnego i ustnego, z którego już raz zrezygnowano (por. Dostatni 2005: 69). Przeciwko rozdzieleniu przemawia już sam fakt, że ustni tłumacze sądowi w praktyce nierzadko MUSZĄ wykonywać również tłumaczenia pisemne. Ponadto rozwiązanie to przyniosłoby ze sobą konieczność zlecania tłumaczenia pisemnego akt sprawy jednemu tłumaczowi (pisemnemu), a powoływanie na rozprawę w tej samej sprawie innego tłumacza (ustnego). W konsekwencji byłoby to niekorzystne i nieefektywne ze względu na powstawanie dodatkowych kosztów i wydłużanie czasu trwania procesu, nie wspominając już o wysoce problemowych aspektach terminologicznych i kwestii zapewnienia wysokiej jakości tłumaczeń. Różnice w tłumaczeniach wykonanych przez dwóch czy kilku różnych tłumaczy mogłyby prowadzić do znacznych rozbieżności ${ }^{26}$, których wyjaśnianie byłoby ponownie kwestią i czasu, i kosztów, a przede wszystkim stanowiłyby podstawę zaskarżenia jakości tłumaczenia przez osobę obcojęzyczną.

Rozdzielenie zawodu wydaje się poza tym być próbą z jednej strony usprawiedliwienia braku kompetencji obecnych tłumaczy przysięłych do tłumaczenia ustnego (leżącego przede wszystkim w wadach systemu kształcenia tłumaczy), a z drugiej próbą podtrzymania starego systemu. Osoby, które chcą się specjalizować tylko w tłumaczeniu pisemnym (literackim, fachowym) lub tylko ustnym (środowiskowym, konferencyjnym) mogą znaleźć odpowiednie miejsce na ogólnym rynku tłumaczeniowym. Wykonywanie zawodu tłumacza przysięgłego, jako zawodu zaufania publicznego związanego $\mathrm{z}$ wielką odpowiedzialnością, nie może być traktowane jako dodatkowe źródło zarobku lub działalność hobbystyczna, prowadząca do naruszania ustawowych obowiązków (nagminne odmowy tłumaczenia na rzecz sądów),

26 Przedstawiciele instytucji już teraz wskazują na istnienie podobnych problemów: „Bardzo często zdarza się, że różni łłumacze powołani do tej samej sprawy tłumaczą to samo słowo całkowicie odmiennie. (...) Często potem zachodzi konieczność dodatkowego wyjaśniania stronie obcej (...)” (Mendel 2011: 9). 
lecz powinno być powierzone wyłącznie osobom o najwyższych kwalifikacjach, mających predyspozycje i kompetencje do wykonywania zarówno tłumaczenia pisemnego, jak i ustnego. O tym, że jest to możliwe świadczy fakt, że w wielu krajach Europy tłumacze przysięgli skutecznie wykonują obydwa rodzaje działalności (przede wszystkim Austria, ale również Czechy, Dania, Grecja, Luksemburg czy Szwajcaria), potwierdzają to także nowo ustanowieni tłumacze przysięgli w Polsce, którzy łączą niezbędne kompetencje, poddając je weryfikacji podczas egzaminu państwowego.

\subsection{Egzamin na tłumacza sądowego}

Nie tylko kształcenie, lecz również egzamin na tłumacza przysięgłego nie może być oderwany od rzeczywistości. Z przepisów Ustawy wynika, że egzamin składa się z tłumaczenia pisemnego oraz tłumaczenia ustnego (art. 4 ust. 1). Skoro więc egzamin weryfikuje kwalifikacje tłumaczy do wykonywania zawodu tłumacza przysięgłego, czyli tłumaczenia pisemnego i ustnego (sądowego), powinien on w części ustnej sprawdzać kompetencję tłumaczenia przede wszystkim ustnego sądowego. Rozporządzenie w sprawie szczegółowego sposobu przeprowadzenia egzaminu na tłumacza przysięgłego (Dz. U. nr 15 poz. 129) faktycznie reguluje, że tłumaczenie ustne polega na tłumaczeniu konsekutywnym i a vista każdorazowo dwóch tekstów, przy czym jeden $\mathrm{z}$ nich powinien być pismem sądowym, urzędowym lub prawniczym ( $\$ 10$ ust 1$)$.

W praktyce bywa jednak inaczej: przykładowo w roku 2009 na egzaminie z języka niemieckiego kandydatom przedłożono do tłumaczenia a vista teksty „Musica sacra a prawo autorskie” oraz przepisy przetłumaczonego na język niemiecki polskiego kodeksu postępowania karnego. Natomiast podczas tłumaczenia konsekutywnego tłumacze musieli się zmierzyć z tekstem "Dlaczego warto inwestować w agregatory kogeneracyjne" oraz z wywiadem dotyczącym inwestycji gospodarczych w Polsce. W takiej formie egzamin jest daleki od weryfikowania kompetencji tłumaczenia ustnego tłumacza sądowego, a co najwyżej sprawdza terminologię i umiejętność tłumaczenia ustnego tekstów specjalistycznych, będących $\mathrm{z}$ reguły przedmiotem konferencji lub spotkań biznesowych, gdzie tłumacz (konferencyjny) ma możliwość gruntownego przygotowania się przed danym tłumaczeniem. Dlatego aby egzamin spełniał swoją rolę i sprawdzał opanowanie technik tłumaczenia ustnego w sądzie, powinien opierać się na autentycznych tekstach pochodzących z rzeczywistości sali sądowej, weryfikując przykładowo tak oczywiste 
i niezbędne umiejętności tłumacza sądowego, jak tłumaczenie aktu oskarżenia, wyroku, przesłuchania świadków.

\subsection{Dostosowanie stawek}

Jeżeli od tłumaczy sądowych wymagane są najwyższe kompetencje i dostarczanie wysokiej jakości usług, nie podlega dyskusji kwestia, że muszą oni za swoją pracę otrzymywać godziwe wynagrodzenie. Niezbędne jest zatem podniesienie stawek ustawowych do takiego stopnia, aby profesjonalny i wykwalifikowany tłumacz podjął się bez wahania zlecenia tłumaczenia dla organów, nie musząc dokonywać oczywistego wyboru w przypadku kolizji terminów, czy podjąć się pracy dla sądu czy tłumaczenia na wolnym rynku.

Trudno jest porównywać polskie realia z sytuacją w Europie Zachodniej, ale dla przykładu można posłużyć się uregulowaniem obowiązującym w Austrii. Wynagrodzenie tłumacza sądowego składa się z trzech elementów $(\$ 24 \mathrm{GebAG})^{27}: 1$. Zwrotu kosztów dojazdu (przejazd tam i z powrotem); 2. Odszkodowanie za utracony czas i możliwość zarobku ( $\$ 32 \mathrm{GebAG)} \mathrm{-}$ kwota ta wynosi 22,70 Euro za każdą rozpoczętą godzinę; 3 . Wynagrodzenie za tłumaczenie i udział w rozprawie ( $\$ 54$ GebAG) - kwota 24,50 Euro za pierwsze rozpoczęte pół godziny, każde następne pół godziny to 12,40 Euro. W przypadku wyższego stopnia trudności stawki wzrastają o ok. 25\%. Jeżeli tłumacz powołany zostaje między godziną 20 a 6, w sobotę, niedzielę lub dzień świąteczny, przysługuje mu $1,5^{\star}$ kwota wyjściowa. Tłumacz ponadto otrzymuje dodatkowe wynagrodzenie za każdą przetłumaczoną stronę pisma sądowego podczas rozprawy oraz za studiowanie akt.

Tylko stawki adekwatne do kwalifikacji i oczekiwań wobec tłumacza, a także koniecznego nakładu pracy, mogą poprawić trudną sytuację na rynku tłumaczenia sądowego (por. 2.3). Terminowe płatności należności przez organa państwowe za terminowo wykonaną pracę tłumacza są oczywistością. Poprawa tych warunków ramowych niewątpliwie przyczyniłaby się do ulepszenia współpracy tłumaczy z organami, a te ostatnie nie miałyby tyle trudności w znalezieniu kompetentnego tłumacza.

${ }^{27}$ Gebührenanspruchsgesetz (BGBl. Nr. 136/1975). 


\subsection{Szkolenia dla przedstawicieli instytucji}

Bez wątpienia wszelkie zmiany należy rozpocząć od środowiska tłumaczy, jednakże poprawie jakości tłumaczenia oraz pozytywnemu wpływowi na przebieg procesu i interakcji sądowej mogłoby służyć także polepszenie współpracy tłumaczy sądowych z organami państwowymi. Taką możliwość daje przeprowadzenie szkoleń dla przedstawicieli instytucji państwowych w zakresie współpracy z tłumaczami sądowymi, zwłaszcza że przewiduje je także dyrektywa unijna (art. 6 2010/64/UE). Warto przy tym podkreślić gotowość środowiska prawniczego, które tego rodzaju zajęcia w ramach kształcenia sędziów, prokuratorów, adwokatów i funkcjonariuszy policji, uważa za przydatne (Mendel 2011: 13).

Celem szkoleń powinno być przede wszystkim uświadomienie pracownikom wymiaru sprawiedliwości specyfiki pracy tłumacza sądowego, jego roli i zadań w postępowaniu karnym oraz charakteru komunikacji pośredniczonej. Istotne byłoby również uwrażliwienie prawników na międzykulturowe aspekty działalności translatorskiej, techniki tłumaczeniowe, znaczenie kontekstu oraz kwestie terminologiczne. Uwzględnić należałoby też sprawę komunikacji z tłumaczami, umożliwienia im poznania tematyki przekładu względnie wglądu do akt oraz udzielania wszelkich niezbędnych informacji.

\section{Literatura}

Błaszkowska, H., 2014, „Universitäre Ausbildung und berufliche Weiterbildung vereidigter Übersetzer und Dolmetscher in Polen“, [w:] New Tasks for Legal Interpreters and Translators in the Enlarged Europe, TEPIS (red.), Warszawa, s. 236-245.

Cieślik, B., Laska, L., Rojewski, M. (red.), 2010, Egzamin na tłumacza przysięgłego: Komentarz, teksty egzaminacyjne, dokumenty, Warszawa.

Dostatni, G., 2005, Komentarz do ustawy o zawodzie tłumacza przysięglego, Warszawa.

European Commission, DG Interpretation (red.), 2009, Reflection Forum on Multilingualism and Interpreter Training. Final Report. http://ec.europa. eu/dgs/scic/docs/finall_reflection_forum_report_en.pdf (dostęp: 7 lipca 2010 r.).

Hertog, E., v. Gucht, J. (red.), 2008, Status quaestionis: Questionnaire on the Provision of Legal Interpreting and Translation in the EU, Antwerp. 
Jopek-Bosiacka, A., 2014, „Court Interpreters' and Legal Translators' Training at the Institute of Applied Liguistics of the University of Warsaw", [w:] New Tasks for Legal Interpreters and Translators in the Enlarged Europe, TEPIS (red.), Warszawa, s. 199-208.

Kabelka, G., 1992, „Die Europäische Menschenrechtskonvention und ihre Auswirkungen auf die Tätigkeit des Gerichtsdolmetschers", [w:] Mitteilungsblatt des Österreichischen Übersetzer- und Dolmetscherverbands UNIVERSITAS I, s. 24-34.

Kadrić, M., 2005, „Der weite Weg nach Europa. Von den Bemühungen der Europäischen Kommission um Qualifizierung der Behördendolmetscherinnen und der (Un)Tätigkeit der Mitgliedstaaten“, [w:] Der Gerichtsdolmetscher 2, s. 27-32.

Kadrić, M., 2009, Dolmetschen bei Gericht. Erwartungen - Anforderungen Kompetenzen, Wien.

Kierzkowska, D., 1992, „Status and Qualifications of Translators and Interpreters in Poland", [w:] Mitteilungsblatt des Österreichischen Übersetzerund Dolmetscherverbands UNIVERSITAS, s. 16-19.

Kierzkowska, D., 2000, „Praktyczne kształcenie tłumaczy prawniczych i sądowych", [w:] O nauczaniu przekładu, A. Setkowicz (red.), Warszawa, s. 131-135.

Kierzkowska, D., 2003, „The status of polish court translators in 2003“, [w:] SlavFile 12 (3), s. 23-25.

Kierzkowska, D. (red.), 2007, Kodeks tłumacza przysiegłego z komentarzem, Warszawa.

Kubacki, A.D., 2012, Tłumaczenie poświadczone: Status, kształcenie, warsztat i odpowiedzialność tłumacza przysięłlego, Warszawa.

Kuipers, E.-J., 2003, „Zwischen Hammer und Amboss: Zur Lage der vereidigten Übersetzer und Dolmetscher in Polen", [w:] Uregulowanie statusu zawodowego tłumacza pisemnego i konferencyjnego $w$ kontekście poszerzenia Unii Europejskiej, WUŁ (red.), Łódź, s. 109-113.

Mendel, A., 2011, Raport z badania ankietowego na temat jakości tłumaczenia w postępowaniu karnym, http://www.tepis.org.pl/pdf-doc/home//r-jtpk. pdf (dostęp: 18 marca 2012 r.).

Morris, R., 1995, „The Moral Dilemmas of Court Interpreting“, [w:] The Translator 1 (1), s. 25-46.

Nartowska, K., 2011, „Tłumaczenie sądowe w Polsce. Analiza rynku”, [w:] Lingua Legis 20, s. 22-29.

Nartowska, K., 2014a, „Court Interpreter: Lawyer, Psychiatrist, Director or Actor?", [w:] New Tasks for Legal Interpreters and Translators in the Enlarged Europe, TEPIS (red.), Warszawa, s. 69-79. 
Nartowska, K., 2014b, Rollenhandeln von DolmetscherInnen in strafgerichtlichen Verfahren. Eine diskursanalytische Studie im Ländervergleich Österreich und Polen, Universität Wien.

Nartowska, K., w druku, „The role of court interpreters in criminal proceedings", [w:] The Interpreters' Newsletter 20.

Soukup-Unterweger, I., 2003, „Gerichtsdolmetscher-Zertifizierung in Österreich", [w:] MDÜ Fachzeitschrift für Dolmetscher und Übersetzer 1, s. 10-13.

Tyupa, S., 2014, „Training of Translators and Interpreters at the Jagiellonian University", [w:] New Tasks for Legal Interpreters and Translators in the Enlarged Europe, TEPIS (red.), Warszawa, s. 196-198.

Żmudzki, J., 2010, „Aktuelle Profile der germanistischen Translationsdidaktik in Polen", [w:] Translation: Theorie-Praxis-Didaktik, A. Małgorzewicz (red.), Dresden-Wrocław, s. 117-146.

\section{Akty prawne}

Bundesgesetz über die allgemein beeideten und gerichtlich zertifizierten Sachverständigen und Dolmetscher (SDG) vom 19. Feber 1975 (BGBl. Nr. 137/1975).

Bundesgesetz vom 19.2.1975 über die Gebühren der Zeugen und Zeuginnen, Sachverständigen, Dolmetscher und Dolmetscherinnen, Geschworenen, Schöffen und Schöffinnen (GebAG) (BGBl. Nr. 136/1975).

Dyrektywa Parlamentu Europejskiego i Rady 2010/64/UE z dnia 20 października $2010 \mathrm{r}$.

$\mathrm{w}$ sprawie prawa do tłumaczenia ustnego i tłumaczenia pisemnego w postępowaniu karnym

Dziennik Urzędowy L 280.

Konwencja o ochronie praw człowieka i podstawowych wolności.

Rozporządzenie Ministra Sprawiedliwości z dnia 8 czerwca 1987 r. w sprawie biegłych sądowych i tłumaczy przysięgłych (Dz. U. nr 18 poz. 112).

Rozporządzenie Ministra Sprawiedliwości z dnia 24 stycznia 2005 r. w sprawie szczegółowego sposobu przeprowadzenia egzaminu na tłumacza przysięgłego (Dz. U. nr 15 poz. 129).

Rozporządzenie Ministra Sprawiedliwości z dnia 24 stycznia 2005 r. w sprawie wynagrodzenia za czynności tłumacza przysięgłego (Dz. U. nr 15 poz. 131).

Ustawa o zawodzie tłumacza przysięgłego z dnia 25 listopada 2004 (Dz. U. nr 273 poz. 2702).

Ustawa z dnia 6 czerwca 1997 r. - Kodeks postępowania karnego (Dz.U. nr 89 poz. 555). 


\section{The Polish Act on the Profession of Sworn Translator and Interpreter and the current situation of court interpreting in Poland}

\section{Summary}

Court interpreters play a key role in bilingual proceedings, as emphasized in Directive 2010/64/EU on the right to interpretation and translation in criminal proceedings. In Poland, the activity of court interpreters is regulated by the Act on the Profession of Sworn Translator. In this paper, the current situation of court interpreting in Poland is subject to a critical reflection in the light of this legislation.

The analysis shows that most Polish sworn translators do not have professional vocational preparation, and they do not feel competent in (court) interpreting. Poland, furthermore, lacks university training for court interpreters, which in turn leads to insufficient quality of interpretation. Moreover, Polish courts have difficulties in finding an interpreter, whereas sworn translators are reluctant to work in the courts. This situation is caused, in addition to the above, by low rates for interpreting, as well as the incomprehension of the nature of the interpreter's work by many institutional representatives.

Thus, it becomes possible to put forward postulates enabling optimisation of the provisions of the Act and the current situation in Poland: changes in translators training, the adaptation of the exam for court interpreters, and the verification of competences of appointed translators would contribute to improving the quality of court interpretation and to safeguarding that only professional interpreters perform court interpreting. At the same time, adequate remuneration for interpreters' work and training of institution representatives would also have an impact on the quality of interpretation and cooperation between interpreters and authorities.

Keywords: court interpreting, court interpreters, sworn translators and interpreters, quality of court interpretation 